Article

\title{
Voluntary Disclosure and Market Valuation of Sustainability Reports in Korea: The Case of Chaebols
}

\author{
Dongheun Lee ${ }^{1}$, Sejoong Lee ${ }^{2, *(D)}$ and Na-Eun Cho ${ }^{3}$ \\ 1 College of Global Business, Korea University, 2511 Sejong-ro, Sejong 30019, Korea \\ 2 College of Business Administration, University of Seoul, 163 Seoulsiripdaero, Dongdaemun-gu, \\ Seoul 02504, Korea \\ 3 College of Business, Hongik University, 94 Wausan-ro, Mapogu, Seoul 04066, Korea \\ * Correspondence: lee0819@uos.ac.kr
}

Received: 19 April 2019; Accepted: 18 June 2019; Published: 28 June 2019

\begin{abstract}
This paper investigates whether chaebol firms tend to issue corporate social responsibility (CSR) reports more than non-chaebol firms. Based on previous studies documenting chaebols' tunneling activities at the expense of other shareholders, we anticipate that chaebol firms are more likely to voluntarily disclose their CSR reports even if investors may discount their values because CSR disclosure is an effective means of window dressing. The empirical results support our expectations. We find that chaebol firms are more likely to disclose CSR reports and a chaebol firm's CSR report disclosure is less evaluated than a non-chaebol firm in the capital market. The result indicates that even if CSR report disclosure may have positive effect on firm value in general, investors may discount the value of chaebol firms' CSR reports.
\end{abstract}

Keywords: corporate social responsibility; sustainability report; chaebol; firm value

\section{Introduction}

A previous study has defined sustainable development as "a development that meets the needs of the present without compromising the ability of future generations to meet their own needs" [1]. In that study, the authors state that a firm level of expression of sustainable development is corporate sustainability, and the social dimension of corporate sustainability is referred to as corporate social responsibility. As a firm's social activities have been emphasized in the achievement of economic and environmental sustainability, research on corporate social responsibility has become one of the main streams in business research [2]. Prior study extends this trend to Korean chaebol cases, documenting that a chaebol-affiliated firm tends to have a high corporate social responsibility (CSR) score because CSR activities may prevent reputation damage of hole group firms or act as an intangible asset [3]. Even if the result is interesting, the study examining the relationship between chaebol affiliation and the firm's determination of voluntary CSR report disclosure is scarce. In this study, we fill this void by investigating the relationship between a chaebol affiliate and its voluntary disclosure activity of CSR report with Korean data. In addition, we also examine the effect of voluntary CSR disclosure of chaebol firms on their stock values to investigate how investors evaluate the voluntary disclosure of CSR reports of chaebol firms.

A chaebol refers to a Korean business group which is a conglomerate of firms that tend to share the same brand name in a variety of industries. Founding families of chaebols control the affiliates of the group and have dominating power over the entire group's business strategies. The Korea Fair Trade Commission (KFTC) defines a chaebol as a business group of firms which are dominated by the group's controlling shareholder, who owns or controls more than $30 \%$ of the firms' shares [4]. 
Chaebols have been developed in Korea as the government has tried to build globally competitive firms after the Korean war by providing special benefits [5]. In Korea, the descendants of founders of chaebols still have dominating power over the group firms.

The dominating power of the founding families of chaebols originates from their extensive voting rights over cash flow rights through pyramidal and cross-shareholdings among chaebol-affiliated firms [6]. The divergence between their voting rights and cash flow rights allows internal corporate governance of chaebol firms to be less effective than non-chaebol firms. Thus, founding families use corporate resources for their own benefits at the expense of the other shareholders, referred to as "tunneling" in previous studies [7,8]. Cases of tunneling are reported on occasion in Korea. For instance, chaebol family members may easily establish and grow their business with the support from their families and at the expense of the other shareholders. They may occupy higher managerial positions at the chaebol firms, where their families are in control, without having sufficient experience. Along with financial benefits, special legal treatment may be provided to people with special connections with large business groups [9]. Because of the privileges that chaebol families have enjoyed, their behaviors receive extensive coverage and criticism in the media, despite the chaebols' contribution to industrial development in Korea.

Our study is an extension of this line of research. We investigate whether chaebol firms are more likely to disclose CSR reports even if investors may discount the value of CSR reports in the market. Under the premise that CSR disclosure is beneficial to the chaebols' controlling families, we anticipate that chaebols may strategically use CSR reports, more than non-chaebols, to dilute their reputation concerns and defend their credibility. This "sustainability communication" through voluntary disclosure of CSR reports may benefit the firm because it helps the firm occupy better positions in the capital market as documented in a previous study [10]. Also, disclosure of CSR reports may meet the interests of investors because investors may demand additional relevant information [11]. As a chaebol is frequently criticized from outside stakeholders because of controlling families' excessive controls and privileges over the affiliates, advertising the firm's CSR activities may be a useful tool in mitigating stakeholders' concerns over the owner risk and justifying controlling families' dominance. Previous studies support our expectations by representing CSR disclosure as an effective way for a firm to conduct window dressing. For example, strategic CSR activities may dilute adverse effects from the low earnings quality of a firm [12]. A manager of the firm is more likely to disclose CSR activities to turn the stakeholders' attention to CSR activities when a firm engages in earnings management. This behavior appears to be more intensified when the firm is big enough and, thus, has high visibility [13]. Also, CSR may act as an insurance scheme for managers by mitigating the external shock or protecting the managers' dominance $[3,14,15]$. Thus, advertisement of CSR activities can fit in well with the founding families' demands to justify their controls over the firms and may be a reasonable choice to maintain their dominance. Thus, we anticipate that chaebol firms have more incentives to disclose their CSR reports than non-chaebol firms. In addition, we also expect that chaebol firms are more likely to disclose their CSR reports when the firms' stock return volatilities are high because highly volatile prices may imply an unstable environment and, thus, investors may demand additional information on the firms $[16,17]$. As the dominance of chaebol managers may be less justified because of the pyramidal and cross-shareholdings of controlling families, we expect they need to signal the firm's sustainability through CSR disclosure to protect their position.

Empirical results support our anticipations. Using voluntary disclosure of sustainability reports as a proxy for voluntary disclosure of CSR reports, we find that chaebol firms are more likely to disclose CSR reports than non-chaebol firms. We also find that the relationship becomes stronger when the volatility of a firm's stock returns is high. Our findings lend support to the idea that chaebol firms may utilize voluntary disclosure of CSR reports to advertise their altruistic activities.

We also investigate the effect of chaebols' voluntary CSR disclosure on firm value. Previous studies have documented that voluntary disclosure of CSR reports may increase firm value in general because it may decrease information asymmetry between managers and investors [18,19]. However, if investors 
expect a chaebol firm's CSR disclosure to reflect the manager's incentive to maintain reputation, the positive effect of CSR disclosure may be weak for chaebol firms. Thus, anticipating a weak relationship between CSR disclosure and firm value, we examine whether the positive effect of CSR disclosure decreases for chaebol firms. The empirical results support our expectations. We find that even if voluntary disclosure of CSR reports increases firm value in general, this effect is small for chaebol firms. The results are still robust when we control for inverse Mill's ratio and apply the propensity score matching process.

The contributions of this study are as follows. First, our result builds upon the previous literature by documenting that CSR disclosure can be exploited for a chaebol manager's benefits. A previous study finds that managers may excessively invest CSR activities to support their reputations and take private benefits [20]. Managers may also use CSR activities to mitigate monitoring from social activists [21]. Another study finds that family firms exploit CSR disclosure when they are engaged in earning management [13]. Thus, our study contributes to this line of literature that presents managers' strategical usage of CSR activities.

Second, this study supplements the previous literature that examines the relationship between CSR and firm value. The majority of previous studies document positive effects of CSR on firm value. For instance, CSR activities may increase firm value by decreasing systemic risk or cost of capital [19,22]. CSR may increase firm value because social contributions lead to future high revenues [23]. Another study shows that voluntary environmental disclosure increases firm value through cash flow and the cost of equity effect [24]. On the other hand, some studies document that CSR undermines shareholders' value [25] or has no effects the firm's financial performance [26]. Our study extends the line of literature by documenting the positive relationship between CSR disclosure and firm value. However, our study is different from previous research in that we show the relationship may vary based on the issuing firm's characteristics by documenting that investors may discount the value of chaebol firms' CSR reports. Thus, our study represents a compromising point with prior literature, enriching the literature.

This paper is organized as follows: we review the prior literature and establish hypotheses in Section 2. In Section 3, we present our research methodology. Section 4 shows empirical results. Finally, Section 5 summarizes and concludes the paper.

\section{Literature Review and Hypotheses}

In spite of its importance and variety of applications, corporate social responsibility is defined in various ways among scholars and experts. The International Organization for Standardization (ISO) defines corporate responsibility as "responsibility of an organization for the impacts of its decisions and activities on society and the environment, through transparent and ethical behavior" [27]. The definition of CSR in the European Commission is "a concept whereby companies integrate social and environmental concerns in their business operations and in their interaction with their stakeholders on a voluntary basis" [28]. CSR is also defined as "Actions that appear to further some social good, beyond the interests of the firm and that which is required by law" [29]. Or, "In essence, CSR is corporate social or environmental behavior that goes beyond the legal or regulatory requirements of the relevant market(s) and/or economy(s)" [2]. To make the concept more clear, a study summarized five dimensions of CSR activities (environmental, social, economic, stakeholder, and voluntariness) by comparing 37 CSR definitions used in academic research [30]. Thus, CSR may be defined as activities beyond what is required by regulations for sustainable growth of society.

A previous study found that a firm's socially responsible attitude eventually benefits by increasing the firm's sustainability [31]. Also, additional voluntary disclosure, such as CSR disclosure, may improve the capital market environment by reducing information asymmetry [32], and investors highly evaluate a firm that engages in CSR activities because CSR is closely related to the firm's corporate governance and monitoring mechanisms [33]. On the other hand, managers may exploit CSR activities for their own benefits. Previous studies have indicated this possibility by documenting 
that CSR may be a useful tool for reputation building [34]. Firms with potential opportunities may invest CSR activities strategically and benefit from such behaviors [35]. Also, investing CSR can be an effective means to attract institutional investors because institutional investors may invest more on firms with high social performance [36]. Supporting the result of the study, a recent study shows that the firm's CSR may have effect on the institutional investors' behavior if the level of CSR activities exceed a certain degree [37].

Thus, our study is based on this line of research that present CSR as a useful tool for reputation management. Extending their implications to Korean chaebol firms, we anticipate that chaebol firms have a stronger incentive to advertise their CSR activities and are thus more likely to voluntarily disclose CSR reports. Our expectation is based on the following reasons. The pyramidal and cross-shareholdings of controlling families provides the room to entrench on minority shareholders' interests $[38,39]$. Thus, compared to other firms, chaebol managers may have more discretion to invest their resources for the managers' reputation-building, such as through CSR activities. Thus, they are more likely to use their resources to advertise their CSR activities through voluntary disclosure of CSR. In addition, high visibility of chaebols may make their CSR disclosure strategy more efficient, as documented in previous study [13]. As CSR can lessen the negative shock from outside of a firm [14], it can also act as an insurance scheme and help protect the managers' control rights. Thus, the controlling families who can pursue excessive private benefit may be more motivated to advertise CSR activities to protect their privileges and disguise their opportunistic behavior. In doing so, the controlling families also alleviate monitoring from active stakeholders [21]. Thus, we establish the first hypothesis.

Hypothesis 1 (H1). Chaebol firms are more likely to voluntarily disclose CSR reports than non-chaebol firms.

Extending H1, we expect that the positive relationship between chaebol firms and voluntary disclosure of CSR reports become stronger when the firms' stock return volatilities are high. As highly volatile prices may imply an unstable environment, the managerial position of the firm may also be less stable [17] and outside investors may demand more information in that situation [16]. Thus, we expect chaebol managers are more likely to disclose CSR reports when the volatility of stock returns is high, because in many situations, their dominance over the chaebol firms is less justified for the pyramidal and cross-shareholdings of controlling families, and they need to signal the firm's sustainable growth and protect their position. Thus, our second hypothesis is as follows:

Hypothesis 2 (H2). Chaebol firms are more likely to disclose CSR reports than non-chaebol firms when their stock returns volatility is higher.

We then investigate the effect of chaebol's voluntary CSR disclosure on the firm value. Even if the majority of prior studies have documented the positive relationship between CSR activities and firm value $[19,22-24]$, the relationship may be weaker for chaebol firms for the following reasons. First, as documented in our H1, chaebol firms may strategically use the CSR disclosure for their own benefits at the expense of other shareholders. In this case, the CSR advertisement may have a decreasing effect on the firm value. Second, if a chaebol manager has incentives to spend the firm's resources to advertise CSR activities, investors may be informed of the manager's incentives and may discount the value of chaebol firms' CSR disclosure. Thus, even if the positive relationship between voluntary disclosure of CSR and firm value is documented in prior study, the effect may be weak for chaebol firms. Thus, the third hypothesis is as follows:

Hypothesis 3 (H3). The positive relationship between CSR disclosure and firm value is weaker for chaebol firms. 


\section{Methodology}

\subsection{Data}

Our key data, voluntary disclosure of CSR reports, was captured by voluntary disclosure of sustainability reports. The sustainability reports were collected through the Business Institute for Sustainable Development (BISD) in Korea. The BISD has collected the sustainability reports for Korean firms and has disclosed their publications on its website. In Korea, issuance of firms' sustainability reports has been continuously growing since they were first published in 2003 . It exceeded 100 for the first time in 2011 and a total of 108 reports were published in 2016. Figure 1 represents the number of sustainability reports published in Korea since 2003.

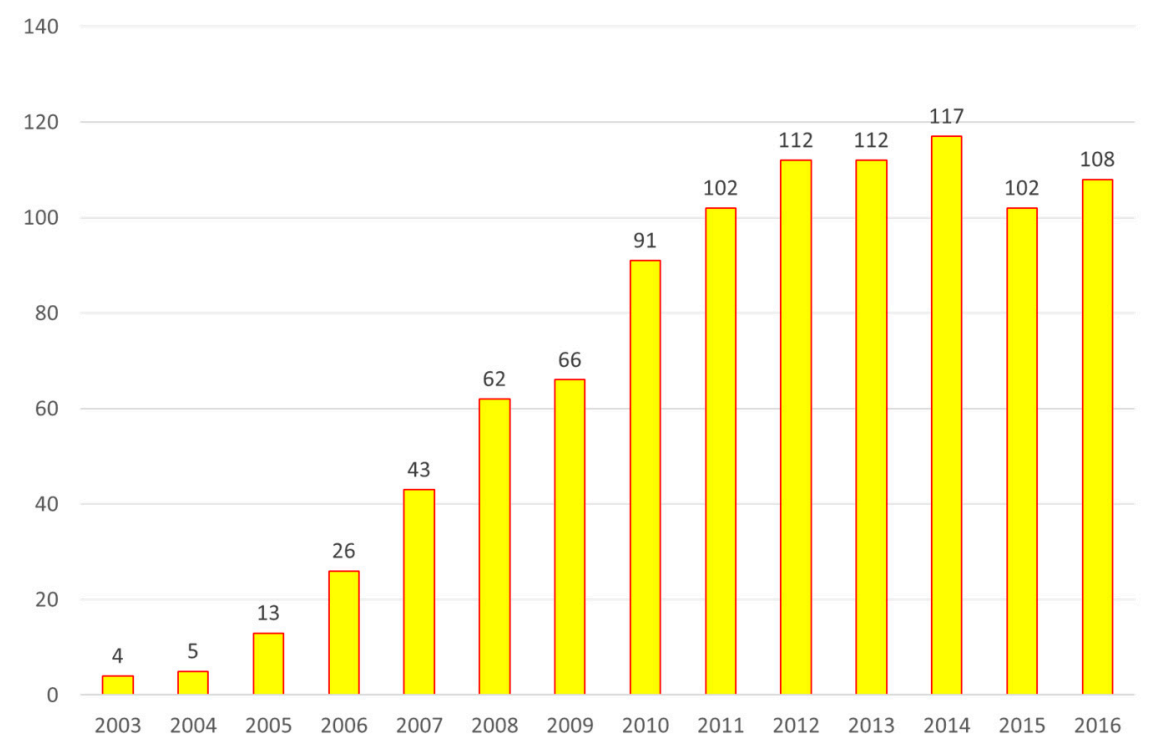

Figure 1. Publication of sustainability reports of Korean firms. Data: Business Institute for Sustainable Development (http://www.bisd.or.kr/eng/introduce/greeting.asp)

As shown in Figure 1, issuance of sustainability reports has been increasing in Korea. However, 100 to 120 firms have published sustainability reports since 2011. The figure indicates that publications of sustainability reports have been stable after 2011. Reflecting this trend, we restrict our sample period from 2011 to 2016 because before 2011, sustainability reports publication may not be fully implemented in Korea.

The corporate social responsibility activity may be associated with voluntary disclosure of sustainability reports. Thus, we also collect "Best Corporate Citizen Index" from the Korea Economic Justice Institute (KEJI). The KEJI has reported the top 200 “Best Corporate Citizen" index since 1991. The best corporate citizens index is annually estimated based on a variety of firm characteristics, such as soundness, social contribution, and employee satisfaction. This index is also referred to as KEJI index, and has been used to measure the corporate social responsibility activites of a firm in previous studies $[40,41]$.

We collected firm-specific financial data from Dataguide. Dataguide is a data analysis system provided by Fnguide, a Korean data compiling company. It covers financial statements, analyst forecasts, stock prices, and returns of individual firms. We merge issuance of sustainability reports and KEJI index with these financial data. Our sample selection criteria are as follows:

(1) Firms that have both financial data and KEJI index at given year;

(2) Firms whose fiscal year end month is December;

(3) Exclude firms belonging to financial industry.

We only collected the data of firms whose fiscal year end month is December in criteria (2) to control for potential effects originating from the difference of fiscal year end month. In criteria (3), 
we exclude financial industries such as banking, pension, and insurance because these industries have different properties from others in their business model and financial reporting.

\subsection{Research Design}

To test our H1, we examine whether chaebol firms are more likely to voluntarily issue sustainability reports. Thus, we adopted an indicator variable as our main dependent variable (Issue), measured as 1 if the firm has issued sustainability report for year $t$ and 0 otherwise. In the empirical regression model, we control for other potential determinants that may make a firm disclose a sustainability report to exclude confounding effects. As whether a firm discloses a sustainability report depends on its disclosure strategy, we refer to the factors from the prior literature that may have an effect on a firm's willingness to disclose more information. As our dependent variable (Issue) is binary, a probit regression model is adopted to test our H1. In the model, coefficients capture the change in $z$-values for the corresponding changes in the independent variables. Our probit regression model to test $\mathrm{H} 1$ is specified as follows:

$$
\begin{aligned}
\text { Probit }\left(\text { Issue }_{=}\right)_{i, t} & =b_{0}+b_{1} \text { Chaebol }_{i, t}+b_{2} \text { Size }_{i, t}+b_{3} \text { Roa }_{i, t}+b_{4} \text { PPE }_{i, t}+b_{5} \text { RnD }_{i, t} \\
& +b_{6} \text { Lev }_{i, t}+b_{7} \text { Volatility }_{i, t}+b_{8} H_{H} I_{i, t}+b_{9} \text { CSRindex }_{i, t} \\
& +b_{10} \text { Director }_{i, t}+b_{11} \text { Outrate }_{i, t}+\epsilon_{i, t}
\end{aligned}
$$

Chaebol is the variable of interest-a value of 1 denotes chaebol firm and 0 denotes the others. If chaebol firms are more likely to voluntarily disclose their sustainability reports, the coefficient, Chaebol $\left(b_{1}\right)$, is expected to have a significant positive sign. If we find a significant positive sign of Chaebol $\left(b_{1}\right)$, it may support our anticipation that chaebol firms may have more incentives to issue sustainability reports to manage their reputations.

We included other variables that may have an effect on a firm's willingness to disclose additional information. We control for firm size (Size). Voluntary disclosure costs may be relatively lower for large firms because the cost per unit of voluntary disclosure can decrease as the firm size increases. In addition, large firms' information dissemination cost may be lower because media and analysts tend to deal with large firms' stories by attending their meetings [42]. Higher firm performance can be associated with additional voluntary disclosure because sufficient resources may facilitate the disclosure [19,42]. Thus, we control for return on assets $(R O A)$ to incorporate this effect. Prior study documents that firms in high-tech industries are more likely to voluntarily provide additional disclosure, such as balance sheet data, because traditional accounting information may be insufficient for them [16]. As these firms tend to invest in intangible assets and spend more for research and development, we control for proportion of tangible assets to total assets $(P P E)$ and proportion of R\&D expenditure to sales $(R n D)$. We also include leverage, measured as the total liabilities to the total assets, because high leverage may intensify the monitoring requirement from outside debt holders [43]. Thus, firms with high leverage may issue more voluntary disclosure. High volatility of stock returns may reflect future earnings uncertainty because expected future earnings are a crucial determinant of stock price [16]. Under the premise that external demand on more information is higher under high uncertainty, we include stock returns volatility (Volatility). When product market competition is intensive, firms tend to conceal their proprietary information to their competitors [44]. Thus, we control for competition with Herfindahl-Hirschman index (HHI). In addition, we also control for "Best Corporate Citizen Index" because firms may advertise their social activities widely by issuing sustainability reports when their current CSR activities are highly valued. Previous studies support this expectation by documenting a positive relationship between a firm's CSR index and its voluntary CSR disclosure [19]. Other than financial variables, we incorporate two corporate governance related variables-number of directors (Director) and the portion of outside directors (Outrate) —in our model to control for board independence following previous studies [45,46]. The definitions of the variables in our model are shown in Table 1. 
Table 1. Definitions of key variables.

\begin{tabular}{|c|c|}
\hline Variables & Descriptions \\
\hline TobinQ & $\begin{array}{l}\text { Tobin's Q, measured as summation of market capitalization and total liability divided } \\
\text { by total assets at the end of year } t\end{array}$ \\
\hline Issue & $\begin{array}{c}\text { An indicator variable, measured as one if the firm issue voluntary sustainability } \\
\text { report for year } t \text { and zero otherwise }\end{array}$ \\
\hline Chaebol & $\begin{array}{c}\text { An indicator variable, measured as one if the firm belongs to chaebol and zero } \\
\text { otherwise }\end{array}$ \\
\hline Size & Firm size, measured as the natural logarithm of total assets at the end of year $t$ \\
\hline Roa & Return on assets, defined as net income divided by the total assets at the end of year $t$ \\
\hline PPE & $\begin{array}{l}\text { Proportion of tangible assets to total assets, measured as tangible assets divided by } \\
\text { total assets at the end of year } t\end{array}$ \\
\hline $\mathrm{RnD}$ & $\begin{array}{l}\text { Proportion of R\&D expenditure to sales, measured as R\&D expenditure divided by } \\
\text { sales at the end of year } t\end{array}$ \\
\hline Lev & Leverage, measured as the total liabilities to the total assets at the end of year $t$ \\
\hline Volatility & $\begin{array}{c}\text { Stock returns volatility, calculated as standard deviation of monthly returns during } \\
\text { year } t\end{array}$ \\
\hline HHI & $\begin{array}{l}\text { Herfindahl-Hirschman Index, estimated as summation of square of sales proportion } \\
\text { of a firm within the industry based on a three-digit KSIC industry classification code } \\
\text { for year } t\end{array}$ \\
\hline CSRindex & $\begin{array}{l}\text { The "Best Corporate Citizen Index" issued by the Korea Economic Justice Institute } \\
\text { (KEJI) which reflect CSR activity of the firm; }\end{array}$ \\
\hline Longtermdebt & $\begin{array}{l}\text { Proportion of long-term debts to total assets, measured as long-term debts divided by } \\
\text { total assets at the end of year } t\end{array}$ \\
\hline Capextosales & $\begin{array}{l}\text { Proportion of capital expenditure to sales, measured as (non-current assets at the end } \\
\text { of year } t \text { less non-current assets at the end of year } t-1 \text { ) divided by sales at the end of } \\
\text { year } t \text {; }\end{array}$ \\
\hline Director & The number of directors at the end of year $t$ \\
\hline Outrate & $\begin{array}{l}\text { The share of outside directors, estimated by the number of outside directors to the } \\
\text { number of directors at the end of year } t\end{array}$ \\
\hline
\end{tabular}

In our $\mathrm{H} 2$, we expect that chaebol firms which are exposed to high stock returns volatility are more likely to issue sustainability reports. Therefore, the following model (2) was constructed by including the interaction variable, Chaebol and Volatility. If our $\mathrm{H} 2$ is supported, the coefficient of interaction variable $\left(b_{2}\right)$ may have a significant positive sign.

$$
\begin{aligned}
{\text { Probit }(\text { Issue }=1)_{i, t}} & =b_{0}+b_{1} \text { Chaebol }_{i, t}+b_{2} \text { Chaebol }_{i, t} \times \text { VoIatilty }_{i, t}+b_{3} \text { Size }_{i, t} \\
& +b_{4} \text { Roa }_{i, t}+b_{5} \text { PPE }_{i, t}+b_{6} \text { RnD }_{i, t}+b_{7} \text { Lev }_{i, t}+b_{8} \text { Volatility }_{i, t} \\
& +b_{9} \text { HHI }_{i, t}+b_{10} \text { CSRindex }_{i, t}+b_{11} \text { Director }_{i, t}+b_{12} \text { Outrate }_{i, t} \\
& +\epsilon_{i, t}
\end{aligned}
$$

In our $\mathrm{H} 3$, we anticipate that the positive effect of CSR disclosure may be mitigated when chaebol firms voluntarily disclose sustainability reports because investors may doubt the incentive of the disclosure of chaebol firms. Before we examine our $\mathrm{H} 3$, we check the relationship between voluntary disclosure of sustainability report and firm value by establishing the following empirical model (3). A firm's value can be captured by stock price because it reflects financial and nonfinancial information about the firm [47]. However, the stock price itself cannot be used because it varies according to the number of outstanding shares and firm size. Thus, Tobin's $Q(T o b i n Q)$ is adopted as our main dependent variable in the model. Tobin's $Q$ is defined as the ratio of market value of equity and liability to the firm's assets. As Tobin's $Q$ reflects the ratio of market's estimated value of the firm's assets 
(liability and equity) to carrying amount of assets and implies the extent to which the firm is managed efficiently by creating economic returns, it is appropriate to estimate the market's value estimation of the firm [48]. If voluntary disclosure of the sustainability report increases firm value, the coefficient of Issue $\left(b_{2}\right)$ may have a significant positive sign.

$$
\begin{aligned}
\text { Tobin }_{i, t} & =b_{0}+b_{1} \text { Chaebol }_{i, t}+b_{2} \text { Issue }_{i, t}+b_{3} \text { Size }_{i, t}+b_{4} \text { PPE }_{i, t}+b_{5} \text { RnD }_{i, t} \\
& +b_{6} \text { HHI }_{i, t}+b_{7} \text { CSRindex }_{i, t}+b_{8} \text { Longtermdebt }_{i, t} \\
& +b_{9} \text { Capextosales }_{i, t}+b_{10} \text { Director }_{i, t}+b_{11} \text { Outrate }_{i, t} \\
& +b_{12} \text { IMR }_{i, t}+\epsilon_{i, t}
\end{aligned}
$$

To examine the effect of chaebol firms' sustainability reports disclosure on their firm value, we construct the following model (4) by supplementing the interaction variable, Chaebol and Issue, in model (3). If our H3 is supported, the coefficient of interaction variable $\left(b_{2}\right)$ may have a significant negative sign.

$$
\begin{aligned}
\text { Tobin }_{i, t} & =b_{0}+b_{1} \text { Chaebol }_{i, t}+b_{2} \text { Issue }_{i, t}+b_{3} \text { Chaebol }_{i, t} \times \text { Issue }_{i, t}+b_{4} \text { Size }_{i, t} \\
& +b_{5} \text { PPE }_{i, t}+b_{6} \text { RnD }_{i, t}+b_{7} \text { HHI I I }_{i, t}+b_{8} \text { CSRindex }_{i, t} \\
& +b_{9} \text { Longtermdebt }_{i, t}+b_{10} \text { Capextosales }_{i, t}+b_{11} \text { Director }_{i, t} \\
& +b_{12} \text { Outrate }_{i, t}+b_{13} \text { IMR }_{i, t}+\epsilon_{i, t}
\end{aligned}
$$

We control for a variety of firm characteristics that may have an effect on firm valuation. A firm's value can be evaluated as high when the firm has more growth opportunities. As small firms are more likely to have growth opportunities than large firms, the value of small firm may be more appreciated. Thus, we control for firm size (Size) [49]. As firms with high intangible assets may be valued more, we include proportion of tangible assets to total assets (PPE) to reflect the firm's capital intensity [50]. In addition, we control for possible determinant of firm value such as research and development expenditures to sales $(R n D)$, long-term debt to total assets (Longtermdebt), and the ratio of capital expenditures to sales (Capextosales), following a previous study [51]. The effect of product market competition on a firm's value is inconclusive. As product market competition may put pressure on executive managers to maximize firm value, the competition may be positively associated with firm value [52]. By contrast, a firm may be undervalued when product market competition is high because profit may revert to mean value fast [53]. To reflect these conflicting anticipations, we control for competition with Herfindahl-Hirschman index (HHI) which captures market competition. Similarly, to control for the relationship between CSR activities and firm value [54], we control for CSR index (CSRindex) estimated with KEJI index, and the number of directors (director) and the portion of outside directors (Outrate) are also controlled for [45,46].

In addition, our empirical model (1) implies that voluntary disclosure of sustainability reports may be determined endogenously and, thus, may have selection bias. When selection bias exists, the coefficient of our regression models cannot truly reflect the effect of voluntary disclosure of sustainability report on firm value. To address this problem, we follow Heckman's two-stage model that uses inverse Mill's ratio [55]. We estimate inverse Mill's ratio (IMR) from our regression result of model (1) and include it in the second stage model—model (3) and (4). This Heckman two-stage method has been widely applied in previous studies to resolve endogenous and self-selection problems [56,57]. 


\section{Empirical Results}

\subsection{Descriptive Statistics}

Table 2 presents descriptive statistics and a comparison of our key variables between chaebol and non-chaebol firms. Among our 850 sample firms, the number of chaebol firms is 186, occupying $21.9 \%$ of our sample. The sample summary in panel A implies that about $8.5 \%$ of sample firms are issuing sustainability reports as indicated in the mean value of Issue. The mean value of Tobin's $Q$ is higher than 1, indicating that, on average, Korean firms are highly valued in capital market relative to their total assets value.

Table 2. Descriptive statistics.

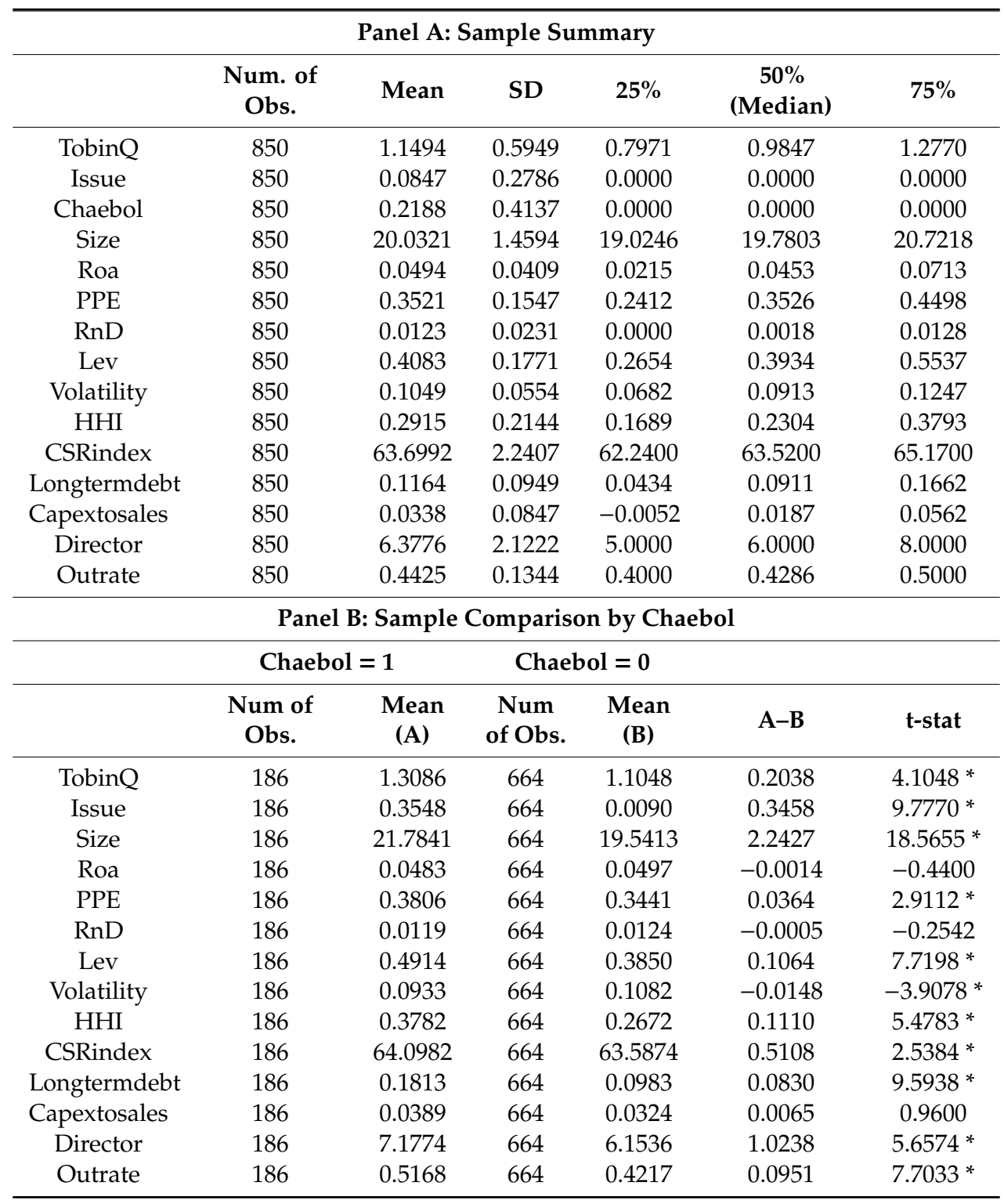

Notes: In the last column, ${ }^{*}$ denotes significance at the $5 \%$ level or lower. 
Panel B compares firm characteristics between chaebol and non-chaebol firms. Importantly, chaebol firms are issuing sustainability reports more than non-chaebol firms as reflected in the difference of Issue. This pattern supports our H1 that chaebol firms are expected to issue more sustainability reports. The difference between chaebol and non-chaebol firms in Table 2 presents useful insights into Korean firms. The mean value of Tobin $Q$ for chaebol firms is significantly higher than the others, implying chaebol firms are highly valued in Korea. Chaebol firms are bigger than the non-chaebol firms as represented in the difference of Size. Interestingly, chaebol sample's HHI index is higher than non-chaebol sample, implying that chaebol firms tend to occupy monopolistic position in their industry. Even if this sample comparison provides useful insights about Korean business environment, the main interest of this study is not the investigation of Korean chaebol firms' business environment. Thus, in this paper, we limit out study to the relationship between chaebol and sustainability report disclosure and its implication in terms of firm value.

Table 3 presents the correlation matrix for our key variables. These pairwise correlations reconfirm our findings shown in Table 2. Issue is significantly related to Chaebol, implying chaebol firms are more likely to issue sustainability reports. Chaebol has a significant positive relationship with TobinQ. It implies that Chaebol firms are more valued in Korea. The table also shows the determinants of Issue. Firm size (Size) is positively associated with issuance of sustainability reports. Highly profitable firms (Roa) are more likely to issue sustainability reports. If a firm is exposed to stock returns volatility, it tends not to issue sustainability reports as documented in the relationship between Volatility and Issue. As represented in the positive relationship between CSRindex and Issue, firms actively engaging in CSR activities also tend to publish sustainability reports. The number of directors (Director) and the portion of outside directors (Outrate) are positively associated with sustainability reports disclosure. In the table, the pairwise correlation coefficients among control variables are located between -0.30 and 0.30 . Thus, we expect that multicollinearity problem may not be so serious. Even if we may find some useful information in the correlation matrix, it should be interpreted carefully because this information is only a pairwise relationship, where other variables are not fully controlled for. 
Table 3. Correlation matrix.

\begin{tabular}{|c|c|c|c|c|c|c|c|c|c|c|c|c|c|c|}
\hline & TobinQ & Issue & Chaebol & Size & Roa & PPE & RnD & Lev & Volatility & HHI & CSRindex & Longtermdebt & Capextosales & Director \\
\hline Issue & $0.1653 *$ & & & & & & & & & & & & & \\
\hline Chaebol & $0.1417^{*}$ & $0.5135 *$ & & & & & & & & & & & & \\
\hline Size & 0.0522 & $0.6022 *$ & $0.6358^{*}$ & & & & & & & & & & & \\
\hline Roa & 0.3970 * & $0.1243 *$ & -0.0145 & 0.0221 & & & & & & & & & & \\
\hline PPE & -0.1201 * & $0.0874 *$ & $0.0974 *$ & $0.1638^{*}$ & -0.1802 * & & & & & & & & & \\
\hline $\mathrm{RnD}$ & $0.2117^{*}$ & 0.0378 & -0.0091 & 0.0215 & $0.0818^{*}$ & -0.0498 & & & & & & & & \\
\hline Lev & -0.0218 & $0.1317^{*}$ & $0.2487 *$ & $0.2587^{*}$ & -0.3745 * & $0.2859 *$ & $-0.1328 *$ & & & & & & & \\
\hline Volatility & 0.1708 * & -0.0816 * & $-0.1107^{*}$ & -0.1895 * & $-0.0685^{*}$ & -0.05 & 0.0099 & 0.2168 * & & & & & & \\
\hline HHI & $0.1603 *$ & $0.1210^{*}$ & 0.2141 * & 0.1091 * & 0.0788 * & 0.0185 & $-0.1838 *$ & $0.0967^{*}$ & -0.0561 & & & & & \\
\hline CSRindex & 0.1436 * & $0.2325 *$ & $0.0943 *$ & $0.2307 *$ & $0.1434 *$ & $0.0818 *$ & $0.1865 *$ & -0.0815 * & -0.0562 & -0.0745 * & & & & \\
\hline Longtermdebt & -0.0345 & $0.1860 *$ & $0.3620 *$ & $0.3964 *$ & -0.2918 * & $0.4552 *$ & 0.0312 & $0.6662 *$ & 0.0525 & 0.0467 & 0.0427 & & & \\
\hline Capextosales & $0.0864 *$ & 0.0207 & 0.0317 & $0.1027 *$ & 0.0226 & $0.1633 *$ & $0.0812 *$ & $0.1018 *$ & 0.0162 & -0.0393 & $0.1367^{*}$ & $0.2548 *$ & & \\
\hline Director & 0.1495 * & $0.1988^{*}$ & $0.1996 *$ & $0.3990 *$ & 0.0561 & 0.0677 * & -0.008 & -0.0084 & $-0.0727^{*}$ & 0.0603 & $0.2399 *$ & $0.0879 *$ & 0.0148 & \\
\hline Outrate & $0.1308^{*}$ & $0.3099 *$ & $0.2926^{*}$ & $0.3324 *$ & $0.0801 *$ & 0.0647 & -0.028 & $0.0993 *$ & -0.0095 & $0.1634 *$ & $0.3051 *$ & $0.1465 *$ & $0.1089 *$ & $0.2404 *$ \\
\hline
\end{tabular}

Notes: This table shows pairwise correlations among the key variables. ${ }^{*}$ Denotes significance at the $5 \%$ level or lower. See Table 1 for variable definitions. 


\subsection{Regression Results}

Table 4 presents the probit regression results regarding determinants of voluntary disclosure of sustainability reports. The coefficient of Chaebol is significantly positive $(0.995, p$-value $<0.05)$ in the first column, implying that chaebol firms are more likely to publish sustainability reports, supporting our H1. The more profitable a firm, the more sustainability reports it issues as indicated by coefficient, Roa $(12.626, p$-value $<0.01)$. The significance of CSRindex $(0.156, p$-value $<0.05)$ implies that when a firm's CSR activities are highly valued, the firm is more likely to issue sustainability report voluntarily.

Table 4. Determinants of voluntary disclosure of sustainability report.

\begin{tabular}{|c|c|c|}
\hline & Probit (Issue = 1) & Probit (Issue $=1$ ) \\
\hline Chaebol & $\begin{array}{l}0.995^{* *} \\
(0.410)\end{array}$ & $\begin{array}{l}-1.447 \\
(0.885)\end{array}$ \\
\hline Chaebol $\times$ Volatility & & $\begin{array}{c}29.391^{* * *} \\
(9.005)\end{array}$ \\
\hline Size & $\begin{array}{c}0.754^{* * *} \\
(0.145)\end{array}$ & $\begin{array}{c}0.806^{* * *} \\
(0.161)\end{array}$ \\
\hline Roa & $\begin{array}{c}12.626^{* * *} \\
(4.051)\end{array}$ & $\begin{array}{c}13.635^{* * *} \\
(4.371)\end{array}$ \\
\hline PPE & $\begin{array}{c}1.203 \\
(0.849)\end{array}$ & $\begin{array}{c}1.193 \\
(0.865)\end{array}$ \\
\hline $\mathrm{RnD}$ & $\begin{array}{l}1.836 \\
(4.771)\end{array}$ & $\begin{array}{c}3.201 \\
(5.275)\end{array}$ \\
\hline Lev & $\begin{array}{c}0.988 \\
(1.079)\end{array}$ & $\begin{array}{c}1.041 \\
(1.074)\end{array}$ \\
\hline Volatility & $\begin{array}{l}-0.788 \\
(3.675)\end{array}$ & $\begin{array}{c}-25.480^{* * *} \\
(6.791)\end{array}$ \\
\hline $\mathrm{HHI}$ & $\begin{array}{l}-0.110 \\
(0.637)\end{array}$ & $\begin{array}{l}-0.245 \\
(0.638)\end{array}$ \\
\hline CSRindex & $\begin{array}{l}0.156^{* *} \\
(0.065)\end{array}$ & $\begin{array}{l}0.159^{* *} \\
(0.066)\end{array}$ \\
\hline Director & $\begin{array}{l}-0.082 \\
(0.072)\end{array}$ & $\begin{array}{l}-0.089 \\
(0.074)\end{array}$ \\
\hline Outrate & $\begin{array}{c}1.420 \\
(0.995)\end{array}$ & $\begin{array}{l}1.523 \\
(0.984)\end{array}$ \\
\hline Constant & $\begin{array}{c}-29.291^{* * *} \\
(4.419)\end{array}$ & $\begin{array}{c}-28.608^{* * *} \\
(4.354)\end{array}$ \\
\hline N. of Obs & 850 & 850 \\
\hline Pseudo $\mathrm{R}^{2}$ & 0.6603 & 0.6767 \\
\hline Prob > chi 2 & 0.0000 & 0.0000 \\
\hline
\end{tabular}

Note: $* * * * *, *$ indicate statistical significance at the $1 \%, 5 \%$, and $10 \%$ levels for two-tailed tests, respectively. Year fixed effects are included. Standard errors clustered by firm are presented in the parentheses.

We examine whether chaebol firms are more likely to disclose sustainability reports voluntarily when current stock returns volatility is high. Column 2 in Table 4 shows the results. The significantly positive sign for Chaebol $\times$ Volatility $(29.391, p$-value $<0.01)$ support our $\mathrm{H} 2$, that chaebol firms disclose sustainability reports voluntarily under higher stock returns volatility.

In Table 5, we investigate the effect of a chaebol firm's voluntary disclosure of sustainability report on firm value. The first column of Table 5 shows the regression result without interaction variable. In the result, we find that chaebol firm is highly valued in Korea as documented in the significant positive sign of Chaebol $(0.196, p$-value $<0.05)$. We examine whether when a chaebol firm issues sustainability reports, the positive effect of Issue is mitigated in the second column of Table 5. The significantly negative sign for Chaebol $\times$ Issue $(-1.553, p$-value $<0.01)$ represent that a chaebol is undervalued when it issues sustainability report, supporting our H3. However, the undervaluation of the chaebol firms that issue sustainability reports does not fully subsume the positive effect of CSR 
disclosure as indicated by the difference between the coefficients of Issue $(1.982, p$-value $<0.01)$ and Chaebol $\times$ Issue $(-1.553, p$-value $<0.01)$. The significant sign of Issue indicates that non-Chaebol firms are highly valued when they issue sustainability reports. The results provide a useful extension to previous studies. The majority of previous studies present observations that CSR activities may increase firm value by decreasing systemic risk or cost of capital [19,22] or leading to future revenue [23] and cash flow. By documenting that this positive effect may be mitigated for chaebol firms, our study provides a novel result. In addition, big firms and firms with more tangible assets tend to be undervalued as documented in the significant negative coefficients of Size and PPE. These results are consistent to our expectation that firms with less growth opportunities and high capital intensity may have lower values. The more a firm invests in $R \& D$, the higher the value of the firm, as shown by the significantly positive coefficient of $R n D$. Similarly, firm value increases when the firm's capital expenditure is high (Capextosales). If a firm's CSR activity is highly evaluated, the firm tends to have a higher market value as documented on the coefficient of CSRindex. In the results, the number of directors (Director) is also an important determinant of firm value.

Table 5. Voluntary disclosure of sustainability report and firm value.

\begin{tabular}{|c|c|c|}
\hline & TobinQ & TobinQ \\
\hline Chaebol & $\begin{array}{c}0.196^{* *} \\
(0.094)\end{array}$ & $\begin{array}{c}0.240 * * * \\
(0.091)\end{array}$ \\
\hline Issue & $\begin{array}{c}0.395 \\
(0.276)\end{array}$ & $\begin{array}{c}1.982 * * * \\
(0.420)\end{array}$ \\
\hline Chaebol $\times$ Issue & & $\begin{array}{c}-1.553^{* * *} \\
(0.378)\end{array}$ \\
\hline Size & $\begin{array}{c}-0.102 * * \\
(0.042)\end{array}$ & $\begin{array}{c}-0.118^{* * *} \\
(0.041)\end{array}$ \\
\hline PPE & $\begin{array}{c}-0.497^{* *} \\
(0.218)\end{array}$ & $\begin{array}{c}-0.595^{* * *} \\
(0.211)\end{array}$ \\
\hline $\mathrm{RnD}$ & $\begin{array}{c}5.221^{* * *} \\
(1.696)\end{array}$ & $\begin{array}{c}5.254^{* * *} \\
(1.721)\end{array}$ \\
\hline $\mathrm{HHI}$ & $\begin{array}{l}0.478 \text { * } \\
(0.248)\end{array}$ & $\begin{array}{l}0.431 \text { * } \\
(0.244)\end{array}$ \\
\hline CSRindex & $\begin{array}{c}0.038^{* * * *} \\
(0.013)\end{array}$ & $\begin{array}{c}0.034^{* * *} \\
(0.013)\end{array}$ \\
\hline Longtermdebt & $\begin{array}{l}-0.150 \\
(0.378)\end{array}$ & $\begin{array}{c}0.082 \\
(0.363)\end{array}$ \\
\hline Capextosales & $\begin{array}{c}0.777^{* * *} \\
(0.258)\end{array}$ & $\begin{array}{c}0.644 \text { ** } \\
(0.257)\end{array}$ \\
\hline Director & $\begin{array}{c}0.048^{* * *} \\
(0.018)\end{array}$ & $\begin{array}{l}0.042 * * \\
(0.018)\end{array}$ \\
\hline Outrate & $\begin{array}{c}0.238 \\
(0.257)\end{array}$ & $\begin{array}{c}0.145 \\
(0.244)\end{array}$ \\
\hline IMR & $\begin{array}{l}-0.070 \\
(0.157)\end{array}$ & $\begin{array}{c}-0.246^{* *} \\
(0.114)\end{array}$ \\
\hline Constant & $\begin{array}{c}0.382 \\
(1.066)\end{array}$ & $\begin{array}{c}1.034 \\
(1.027)\end{array}$ \\
\hline $\begin{array}{c}\text { N. of Obs } \\
\text { adj. R-sq } \\
\text { F-statistics }\end{array}$ & $\begin{array}{c}850 \\
0.177 \\
4.107\end{array}$ & $\begin{array}{c}850 \\
0.213 \\
6.190\end{array}$ \\
\hline
\end{tabular}

Note: ${ }^{* * *},{ }^{* *},{ }^{*}$ indicate statistical significance at the $1 \%, 5 \%$, and $10 \%$ levels for two-tailed tests, respectively. Year fixed effects are included. Standard errors clustered by firm are presented in the parentheses. IMR: inverse Mill's ratio.

\subsection{Additional Analysis}

We have applied Heckman's two-stage method to control for potential endogeneity and self-selection bias in our empirical model. To further check the robustness of our empirical results 
and to control for a variety of firm characteristics, we adopt a propensity score matching approach (hereafter, PSM matching) [57]. PSM matching helps to compare chaebols and non-chaebols with similar characteristics by estimating their propensity scores, and may provide more direct estimates of the difference between chaebol and non-chaebol firms. For example, chaebol firms may be more likely to issue sustainability reports because chaebol firms tend to have high net income in Korea, or because their size is big. Under these situations, the difference between chaebol and non-chaebol firms may merely reflect chaebol firms' different socioeconomic conditions, rather than chaebol factors. In PSM matched samples, chaebol firms are matched to non-chaebol firms that share similar properties. Thus, Chaebol firms' different socioeconomic conditions can be excluded. Propensity score is estimated with the probit model by regressing Chaebol against the control variables. In samples matched through this procedure, the differences between chaebol and non-chaebol samples are minimized, with the exception of Chaebol itself.

Table 6 compares the differences between chaebol and non-chaebol samples. The numbers of observations are the same in both samples due to the matching process. We provide two matched samples in Table 6. Panel A represents a PSM matched sample that fully covers 186 Chaebol firms contained in our original sample. We define it as a full matched sample. We still find that several firm characteristics, such as Size, Lev, HHI, CSRindex, Longtermdebt, Director, and Outrate are not fully excluded in the sample, even after PSM matching process, because of the sizable initial differences between chaebol and non-chaebol firms. Thus, we constructed another PSM matched sample in Panel B. In this sample, we made adjustments so that there were no significantly different firm characteristics between chaebol and non-chaebol firms, except regarding Issue. We constructed the sample by dropping observations in which the discrepancy between the propensity score of a chaebol firm and the score of its matched sample did not fall into a certain range which was more strictly assigned. We defined this more rigorously constituted sample as an adjusted matched sample. In the adjusted matched sample in Panel B of Table 6, the differences between chaebol and non-chaebol firms disappear, except Issue, demonstrating that the matching process was effective. The significant differences observed for Issue in both samples show that sustainability report issuance still survives even after the matching procedure, implying that chaebol firms are more likely to issue sustainability reports, supporting our H1.

Table 7 presents our replication of Table 4 with PSM matched sample. The coefficients of Chaebol are still significantly positive $(0.900, p$-value $<0.05$ and $2.139, p$-value $<0.01$, respectively) in the first and third columns. In the second and fourth columns, the significant positive signs of Chaebol $\times$ Volatility (34.147, $p$-value $<0.01$ and $18.918, p$-value $<0.10$, respectively) are qualitatively similar to our prior results. These additional results imply that chaebol firms are more likely to voluntarily disclose sustainability reports and the tendency is intensified when current stock returns volatility is high, supporting our $\mathrm{H} 1$ and $\mathrm{H} 2$.

Table 8 is the replicated results of Table 5 with PSM matched sample. Unlike Table 5 , the coefficients of Issue are significantly positive $(0.819, p$-value $<0.05$ and $1.472, p$-value $<0.01$, respectively) in the first and third columns. The results indicate that voluntary disclosure of sustainability reports may increase market value in general. As represented in the second and fourth columns, coefficients of Chaebol $\times$ Issue $(-1.429, p$-value $<0.01$ and $-1.209, p$-value $<0.05$, respectively) are significantly negative while coefficients of Issue are significantly positive (2.130, $p$-value $<0.01$ and $2.520, p$-value $<0.01$, respectively. These results indicate that even if voluntary disclosure of sustainability reports may be advantageous to increasing firm value in general, the effect may be small for chaebol firms. This implies that the market may discount the virtue of chaebol firms' voluntary disclosure of sustainability reports, supporting our $\mathrm{H} 3$. 
Table 6. Descriptive statistics for the matched sample.

\begin{tabular}{|c|c|c|c|c|c|c|}
\hline \multicolumn{7}{|c|}{ Panel A: Full matched sample } \\
\hline & \multicolumn{2}{|c|}{ Chaebol = 1} & \multicolumn{2}{|c|}{ Chaebol $=0$} & \multirow[b]{2}{*}{ A-B } & \multirow[b]{2}{*}{ t-stat } \\
\hline & $\begin{array}{l}\text { Num of } \\
\text { Obs. }\end{array}$ & $\begin{array}{l}\text { Mean } \\
\text { (A) }\end{array}$ & $\begin{array}{c}\text { Num of } \\
\text { Obs. }\end{array}$ & $\begin{array}{l}\text { Mean } \\
\text { (B) }\end{array}$ & & \\
\hline Issue & 186 & 0.3548 & 186 & 0.0323 & 0.32258 & $8.6023 *$ \\
\hline Size & 186 & 21.7841 & 186 & 20.5192 & 1.26488 & $9.8568 *$ \\
\hline Roa & 186 & 0.0483 & 186 & 0.0467 & 0.00152 & 0.3747 \\
\hline PPE & 186 & 0.3806 & 186 & 0.3642 & 0.01633 & 0.9961 \\
\hline $\mathrm{RnD}$ & 186 & 0.0119 & 186 & 0.0120 & -0.0001 & -0.0466 \\
\hline Lev & 186 & 0.4914 & 186 & 0.4337 & 0.05774 & 3.2730 * \\
\hline Volatility & 186 & 0.0933 & 186 & 0.1029 & -0.0096 & -1.9501 \\
\hline $\mathrm{HHI}$ & 186 & 0.3782 & 186 & 0.3276 & 0.0506 & $1.9622 *$ \\
\hline CSRindex & 186 & 64.0982 & 186 & 63.5711 & 0.52715 & $2.0960 *$ \\
\hline Longtermdebt & 186 & 0.1813 & 186 & 0.1430 & 0.03831 & 3.5651 * \\
\hline Capextosales & 186 & 0.0389 & 186 & 0.0335 & 0.00534 & 0.5869 \\
\hline Director & 186 & 7.1774 & 186 & 6.6344 & 0.54301 & 2.3291 * \\
\hline Outrate & 186 & 0.5168 & 186 & 0.4394 & 0.07741 & 5.3019 * \\
\hline \multicolumn{7}{|c|}{ Panel B: Adjusted matched sample } \\
\hline & \multicolumn{2}{|c|}{ Chaebol = 1} & \multicolumn{2}{|c|}{ Chaebol $=0$} & & \\
\hline & $\begin{array}{l}\text { Num of } \\
\text { Obs. }\end{array}$ & $\begin{array}{l}\text { Mean } \\
\text { (A) }\end{array}$ & $\begin{array}{c}\text { Num of } \\
\text { Obs. }\end{array}$ & $\begin{array}{l}\text { Mean } \\
\text { (B) }\end{array}$ & A-B & t-stat \\
\hline Issue & 106 & 0.1698 & 106 & 0.0377 & 0.13208 & $3.2142 *$ \\
\hline Size & 106 & 20.8265 & 106 & 20.5830 & 0.2435 & 1.6368 \\
\hline Roa & 106 & 0.0477 & 106 & 0.0509 & -0.0032 & -0.6171 \\
\hline PPE & 106 & 0.3921 & 106 & 0.3724 & 0.01974 & 0.8775 \\
\hline $\mathrm{RnD}$ & 106 & 0.0123 & 106 & 0.0100 & 0.00226 & -0.6457 \\
\hline Lev & 106 & 0.4525 & 106 & 0.4472 & 0.00528 & 0.2190 \\
\hline Volatility & 106 & 0.0984 & 106 & 0.0923 & 0.0061 & 1.0004 \\
\hline $\mathrm{HHI}$ & 106 & 0.3432 & 106 & 0.3388 & 0.00443 & 0.1257 \\
\hline CSRindex & 106 & 63.8256 & 106 & 63.6705 & 0.1551 & 0.4825 \\
\hline Longtermdebt & t 106 & 0.1563 & 106 & 0.1460 & 0.01034 & 0.6936 \\
\hline Capextosales & 106 & 0.0368 & 106 & 0.0344 & 0.00238 & 0.2065 \\
\hline Director & 106 & 6.8585 & 106 & 6.5472 & 0.31132 & 0.9493 \\
\hline Outrate & 106 & 0.4703 & 106 & 0.4503 & 0.01996 & 1.0052 \\
\hline
\end{tabular}

Notes: In the last column, ${ }^{*}$ denotes significance at the $5 \%$ level or lower.

Table 7. Determinants of voluntary disclosure of sustainability report in propensity score matching (PSM) matched sample.

\begin{tabular}{ccccc}
\hline & \multicolumn{2}{c}{ Full Matched Sample } & \multicolumn{2}{c}{ Adjusted Matched Sample } \\
\cline { 2 - 5 } & Probit (Issue = 1) & Probit (Issue = 1) & Probit (Issue = 1) & Probit (Issue = 1) \\
\hline Chaebol & $0.900^{* *}$ & $-1.937^{* *}$ & $2.139^{* * *}$ & 0.507 \\
Chaebol $\times$ & $(0.382)$ & $(0.924)$ & $(0.656)$ & $(1.073)$ \\
Volatility & & $34.147^{* * *}$ & & $18.918^{*}$ \\
& & $(10.227)$ & 0.450 & $(10.995)$ \\
Size & $0.779^{* * *}$ & $(0.286)$ & 0.510 \\
Roa & $\left(0.730^{* * *}\right.$ & $14.318^{* * *}$ & $36.877^{* * *}$ & $(0.314)$ \\
& $13.532^{* * *}$ & $(4.779)$ & $(7.161)$ & $35.970 * *$ \\
PPE & $(4.412)$ & 1.150 & 0.809 & $(6.811)$ \\
& 1.164 & $(0.868)$ & $(1.182)$ & 0.696 \\
\end{tabular}


Table 7. Cont.

\begin{tabular}{ccccc}
\hline & \multicolumn{2}{c}{ Full Matched Sample } & \multicolumn{2}{c}{ Adjusted Matched Sample } \\
\cline { 2 - 5 } & Probit (Issue = 1) & Probit (Issue = 1) & Probit (Issue = 1) & Probit (Issue = 1) \\
\hline RnD & 1.054 & 2.992 & -4.653 & -4.707 \\
& $(4.968)$ & $(5.910)$ & $(7.904)$ & $(8.169)$ \\
Lev & 0.996 & 1.027 & $3.576^{* *}$ & $3.237^{* *}$ \\
& $(1.114)$ & $(1.097)$ & $(1.530)$ & $(1.440)$ \\
Volatility & -0.677 & $-30.624^{* * *}$ & -6.349 & $-22.200^{* *}$ \\
& $(3.886)$ & $(8.363)$ & $(4.527)$ & $(10.366)$ \\
HHI & -0.224 & -0.459 & -0.388 & -0.645 \\
& $(0.643)$ & $(0.671)$ & $(0.645)$ & $(0.715)$ \\
CSRindex & $0.165^{* *}$ & $0.167^{* *}$ & $0.449 * * *$ & $0.446^{* * *}$ \\
& $(0.067)$ & $(0.068)$ & $(0.148)$ & $(0.147)$ \\
Director & -0.084 & -0.098 & -0.205 & -0.238 \\
& $(0.076)$ & $(0.077)$ & $(0.134)$ & $(0.145)$ \\
Outrate & 1.309 & 1.391 & 2.303 & 1.919 \\
& $(0.946)$ & $(0.929)$ & $(1.406)$ & $(1.307)$ \\
Constant & $-29.087^{* * *}$ & $-27.833^{* * *}$ & $-43.848^{* * *}$ & $-43.010^{* * *}$ \\
& $(4.514)$ & $(4.420)$ & $(10.279)$ & $(10.113)$ \\
\hline N. of Obs & 372 & 372 & 212 & 212 \\
Pseudo $R^{2}$ & 0.5499 & 0.5740 & 0.5863 & 0.5961 \\
Prob $>$ chi2 & 0.0000 & 0.0000 & 0.0000 & 0.0000 \\
\hline
\end{tabular}

Note: ${ }^{* * *}, * * *$ indicate statistical significance at the $1 \%, 5 \%$, and $10 \%$ levels for two-tailed tests, respectively. Year fixed effects are included. Standard errors clustered by firm are presented in the parentheses.

Table 8. Voluntary disclosure of sustainability report and firm value in PSM matched sample.

\begin{tabular}{|c|c|c|c|c|}
\hline & \multicolumn{2}{|c|}{ Full Matched Sample } & \multicolumn{2}{|c|}{ Adjusted Matched Sample } \\
\hline & TobinQ & TobinQ & TobinQ & TobinQ \\
\hline \multirow[t]{2}{*}{ Chaebol } & 0.108 & 0.180 ** & 0.053 & 0.122 \\
\hline & $(0.096)$ & $(0.091)$ & $(0.101)$ & $(0.098)$ \\
\hline \multirow[t]{2}{*}{ Issue } & $0.819^{* *}$ & $2.130 * * *$ & $1.472 * * *$ & $2.520 * * *$ \\
\hline & $(0.367)$ & $(0.442)$ & $(0.435)$ & $(0.467)$ \\
\hline \multirow[t]{2}{*}{ Chaebol $\times$ Issue } & & $-1.429^{* * *}$ & & $-1.209^{* *}$ \\
\hline & & $(0.367)$ & & $(0.469)$ \\
\hline \multirow[t]{2}{*}{ Size } & $-0.190 * * *$ & $-0.174^{* *}$ & -0.090 & -0.083 \\
\hline & $(0.072)$ & $(0.074)$ & $(0.068)$ & $(0.066)$ \\
\hline \multirow[t]{2}{*}{ PPE } & $-0.481 *$ & $-0.672 * * *$ & $-0.707^{* *}$ & $-0.790^{* * *}$ \\
\hline & $(0.275)$ & $(0.245)$ & $(0.298)$ & $(0.287)$ \\
\hline \multirow[t]{2}{*}{$\mathrm{RnD}$} & $5.722 * * *$ & $5.774 * * *$ & 5.970 ** & $5.828 * *$ \\
\hline & $(1.918)$ & $(1.938)$ & $(2.344)$ & $(2.283)$ \\
\hline \multirow[t]{2}{*}{$\mathrm{HHI}$} & 0.323 & 0.296 & $0.550 *$ & 0.476 \\
\hline & $(0.256)$ & $(0.245)$ & $(0.312)$ & $(0.306)$ \\
\hline \multirow[t]{2}{*}{ CSRindex } & -0.001 & -0.004 & -0.029 & -0.038 \\
\hline & $(0.019)$ & $(0.018)$ & $(0.031)$ & $(0.031)$ \\
\hline \multirow[t]{2}{*}{ Longtermdebt } & -0.318 & 0.057 & -0.438 & -0.086 \\
\hline & $(0.537)$ & $(0.504)$ & $(0.571)$ & $(0.555)$ \\
\hline \multirow[t]{2}{*}{ Capextosales } & $0.757^{* *}$ & 0.522 * & $1.358^{* * *}$ & $1.031 * *$ \\
\hline & $(0.297)$ & $(0.299)$ & $(0.432)$ & $(0.446)$ \\
\hline \multirow[t]{2}{*}{ Director } & $0.059^{* * *}$ & $0.046^{* *}$ & $0.059 * *$ & $0.052 *$ \\
\hline & $(0.022)$ & $(0.022)$ & $(0.028)$ & $(0.028)$ \\
\hline \multirow[t]{2}{*}{ Outrate } & 0.102 & 0.021 & -0.253 & -0.295 \\
\hline & $(0.360)$ & $(0.331)$ & $(0.530)$ & $(0.482)$ \\
\hline \multirow[t]{2}{*}{ IMR } & $-0.324 * *$ & $-0.379 * *$ & $-0.622 * * *$ & $-0.693^{* * *}$ \\
\hline & $(0.154)$ & $(0.146)$ & (0.170) & $(0.160)$ \\
\hline \multirow{2}{*}{ Constant } & $4.629 * *$ & $4.586 * *$ & $4.371^{*}$ & $4.800 * *$ \\
\hline & $(1.892)$ & $(1.889)$ & $(2.446)$ & $(2.339)$ \\
\hline N. of Obs & 0.238 & 0.307 & 0.353 & 0.394 \\
\hline adj. R-sq & 0.202 & 0.272 & 0.297 & 0.338 \\
\hline F-statistics & 3.592 & 5.975 & 3.401 & 5.375 \\
\hline
\end{tabular}

Note: $* * * * *, *$ indicate statistical significance at the $1 \%, 5 \%$, and $10 \%$ levels for two-tailed tests, respectively. Year fixed effects are included. Standard errors clustered by firm are presented in the parentheses. 


\section{Discussion and Conclusions}

Recently, a firm's CSR activity has been emphasized in academia as CSR is considered as one of crucial factors for economic and environmental sustainability. Thus, encouraging voluntary disclosure of CSR reports may help society as a whole by providing the information regarding a firm's effort to harmonize the interests of the firm and society. However, controlling managers enjoying excessive privileges, such as chaebol families, may exploit CSR disclosure to support their reputation and maintain their dominating power. By investigating chaebol and voluntary disclosure of CSR reports, this study addresses this issue. We show that chaebol firms are more likely to issue CSR reports voluntarily. The result is consistent with our expectation that a chaebol may use voluntary disclosure of CSR for their reputation management. In addition, based on the rationale that investors may discount firm value if chaebol firms use CSR disclosure for their own dominance at the expense of other shareholders, we examine the relationship between chaebols' voluntary CSR disclosure and firm value. The empirical results show that there is less increase in a firm's value when a chaebol firm discloses CSR report voluntarily, supporting our anticipation. The result implies that investors doubt chaebols' intentions regarding CSR disclosure and therefore discount its value.

This study contributes to the literature by extending upon previous studies that examine the relationship between chaebol affiliation and CSR score to the relationship between chaebol affiliation and voluntary CSR disclosure. On the other hand, this study provides a compromising point with prior literature. Different from previous studies documenting the positive relationship between CSR disclosure and firm value, our study shows that the effect may vary depending on the firm's characteristics by documenting that investors may react negatively to the CSR disclosure of chaebol firms. Overall, our study presents useful implications about CSR disclosure of a chaebol firm and capital market evaluation. In addition, it also contributes to a firm's disclosure policy and corporate governance. The result indicates that managers of chaebol firms should be more sophisticated when they issue sustainability reports, considering the cost of disclosure and positive effects. If chaebol managers want to increase the positive effects of CSR disclosure, they may need to mitigate investors' concerns about the motivation of chaebol firms' CSR disclosure. We expect this study may provide a useful milestone for future studies by introducing the determinants of CSR disclosure and their effects on firm value.

Despite its contributions, we admit several limitations of this study. First, our study used an indicator variable which is 1 if the firm is a chaebol affiliate. Thus, our study does not represent the specific factors that help chaebol firms to issue more CSR reports. Second, there may also be differences among chaebol firms. However, an underlying assumption of our analysis is that chaebol firms may share common characteristics because we employ indicator variable representing chaebol firms. Thus, this study is not free from the potential information loss originating from differences across chaebol firms. Third, even though we find that investors undervalue voluntary CSR disclosure of chaebol firms, our study does not provide the specific reasons at this stage. Fourth, our study focuses on whether a firm issue CSR reports or not. However, different firms may issue different types of CSR reports. Thus, analyzing the contents of CSR reports through textual analyses may be a testable area while, currently, our study does not cover this issue.

Thus, potential areas for future research include examining the specific factors making the chaebol firms disclose CSR reports. Also, comparing CSR disclosure activities within chaebol firms may be a promising future research project. In addition, the variation of the value discount of chaebols' CSR disclosure according to investors' types (e.g., dedicated investors vs. transient investors) may provide helpful insights from the perspective of capital market. Also, textual analysis of CSR reports may be a useful extension of our study.

Author Contributions: D.L. summarized prior literature and supplemented empirical analysis; S.L. proposed the idea and wrote major parts of the paper; N.-E.C. supplemented several parts of the paper and refined the whole.

Funding: For Na-Eun Cho, this work was supported by 2018 Hongik University Research Fund. 
Acknowledgments: We appreciate the data provision of Business Institute for Sustainable Development (BISD).

Conflicts of Interest: The authors declare no conflict of interest.

\section{References}

1. Tureac, C.; Turtureanu, A.; Bordean, I.; Georgeta, M. Corporate Social Responsibility and Sustainable Development. 2009. Available online: https://econpapers.repec.org/article/dugactaec/y_3a2009_3ai_3a1_ 3ap_3a111-118.htm (accessed on 22 May 2019).

2. Kitzmueller, M.; Shimshack, J. Economic Perspectives on Corporate Social Responsibility. J. Econ. Lit. 2012, 50, 51-84. [CrossRef]

3. Choi, J.J.; Jo, H.; Kim, J.; Kim, M.S. Business Groups and Corporate Social Responsibility. J. Bus. Ethics 2018, 153, 931-954. [CrossRef]

4. Moskalev, S.; Park, S.C. South Korean chaebols and value-based management. J. Bus. Ethics 2010, 92, 49-62. [CrossRef]

5. Campbell, T.L.; Keys, P.Y. Corporate governance in South Korea: The chaebol experience. J. Corp. Financ. 2002, 8, 373-391. [CrossRef]

6. Song, K.R.; Mantecon, T.; Altintig, Z.A. Chaebol-affiliated analysts: Conflicts of interest and market responses. J. Bank. Financ. 2012, 36, 584-596. [CrossRef]

7. Baek, J.-S.; Kang, J.-K.; Lee, I. Business Groups and Tunneling: Evidence from Private Securities Offerings by Korean Chaebols. J. Financ. 2006, 61, 2415-2449. [CrossRef]

8. Johnson, S.; Porta, R.L.; Lopez-de-Silanes, F.; Shleifer, A. Tunneling. Am. Econ. Rev. 2000, 90, $22-27$. [CrossRef]

9. Choi, H.; Kang, H.G.; Kim, W.; Lee, C.; Park, J. Too Big to Jail? Company Status and Judicial Bias in an Emerging Market. Corp. Gov. Int. Rev. 2016, 24, 85-104. [CrossRef]

10. Jianu, I.; Ţurlea, C.; Guşatu, I. The Reporting and Sustainable Business Marketing. Sustainability 2016, 8, 23. [CrossRef]

11. Jianu, I.; Jianu, I.; Turlea, C. Measuring the Company's Real Performance by Physical Capital Maintenance. 2017. Available online: https://papers.ssrn.com/sol3/papers.cfm?abstract_id=3136613 (accessed on 6 June 2019).

12. Choi, B.B.; Lee, D.; Park, Y. Corporate Social Responsibility, Corporate Governance and Earnings Quality: Evidence from Korea. Corp. Gov. Int. Rev. 2013, 21, 447-467. [CrossRef]

13. Gavana, G.; Gottardo, P.; Moisello, A.M. Earnings management and CSR disclosure. Family vs. non-family firms. Sustainability 2017, 9, 2327. [CrossRef]

14. Lins, K.V.; Servaes, H.; Tamayo, A.N.E. Social Capital, Trust, and Firm Performance: The Value of Corporate Social Responsibility during the Financial Crisis. J. Financ. 2017, 72, 1785-1824. [CrossRef]

15. Chiu, S.-C.; Sharfman, M. Corporate Social Irresponsibility and Executive Succession: An Empirical Examination. J. Bus. Ethics 2018, 149, 707-723. [CrossRef]

16. Chen, S.; DeFond, M.L.; Park, C.W. Voluntary disclosure of balance sheet information in quarterly earnings announcements. J. Account. Econ. 2002, 33, 229-251. [CrossRef]

17. Peters, F.S.; Wagner, A.F. The Executive Turnover Risk Premium. J. Financ. 2014, 69, 1529-1563. [CrossRef]

18. Francis, J.; Nanda, D.; Olsson, P.E.R. Voluntary Disclosure, Earnings Quality, and Cost of Capital. J. Account. Res. 2008, 46, 53-99. [CrossRef]

19. Dhaliwal, D.S.; Li, O.Z.; Tsang, A.; Yang, Y.G. Voluntary Nonfinancial Disclosure and the Cost of Equity Capital: The Initiation of Corporate Social Responsibility Reporting. Account. Rev. 2011, 86, 59-100. [CrossRef]

20. Barnea, A.; Rubin, A. Corporate Social Responsibility as a Conflict between Shareholders. J. Bus. Ethics 2010, 97, 71-86. [CrossRef]

21. Cespa, G.; Cestone, G. Corporate Social Responsibility and Managerial Entrenchment. J. Econ. Manag. Strateg. 2007, 16, 741-771. [CrossRef]

22. Albuquerque, R.; Koskinen, Y.; Zhang, C. Corporate Social Responsibility and Firm Risk: Theory and Empirical Evidence. Manage. Sci. 2018. [CrossRef]

23. Lev, B.; Petrovits, C.; Radhakrishnan, S. Is doing good good for you? how corporate charitable contributions enhance revenue growth. Strateg. Manag. J. 2010, 31, 182-200. [CrossRef] 
24. Plumlee, M.; Brown, D.; Marshall, R.S. Voluntary Environmental Disclosure Quality and Firm Value: Further Evidence. J. Acc. Public Policy 2010, 34, 1-41. [CrossRef]

25. Chen, Y.C.; Hung, M.; Wang, Y. The effect of mandatory CSR disclosure on firm profitability and social externalities: Evidence from China. J. Account. Econ. 2018, 65, 169-190. [CrossRef]

26. McWilliams, A.; Siegel, D. Corporate social responsibility and financial performance: Correlation or misspecification? Strateg. Manag. J. 2000, 21, 603-609. [CrossRef]

27. The International Organization for Standardization. ISO 26000 and OECD Guidelines: Practical Overview of the Linkages; The International Organization for Standardization: Geneva, Switzerland, 2017.

28. Commission of the European Communities. Communication from the Commission Concerning Corporate Social Responsibility: A Business Contribution to Sustainable Development; Commission of the European Communities: Brussels, Belgium, 2002.

29. McWilliams, A.; Siegel, D. Corporate Social Responsibility: A Theory of the Firm Perspective. Acad. Manag. Rev. 2001, 26, 117-127. [CrossRef]

30. Dahlsrud, A. How corporate social responsibility is defined: An analysis of 37 definitions. Corp. Soc. Responsib. Environ. Manag. 2008, 15, 1-13. [CrossRef]

31. Mishra, S.; Suar, D. Does Corporate Social Responsibility Influence Firm Performance of Indian Companies? J. Bus. Ethics 2010, 95, 571-601. [CrossRef]

32. Dhaliwal, D.S.; Radhakrishnan, S.; Tsang, A.; Yang, Y.G. Nonfinancial disclosure and analyst forecast accuracy: International evidence on corporate social responsibility disclosure. Account. Rev. 2012, 87, 723-759. [CrossRef]

33. Jo, H.; Harjoto, M.A. Corporate Governance and Firm Value: The Impact of Corporate Social Responsibility. J. Bus. Ethics 2011, 103, 351-383. [CrossRef]

34. Brammer, S.; Pavelin, S. Building a Good Reputation. Eur. Manag. J. 2004, 22, 704-713. [CrossRef]

35. Mishra, D.R. Post-innovation CSR Performance and Firm Value. J. Bus. Ethics 2017, 140, 285-306. [CrossRef]

36. Graves, S.B.; Waddock, S.A. Institutional Owners and Corporate Social Performance. Acad. Manag. J. 1994, 37, 1034-1046.

37. Wang, M.; Qiu, C.; Kong, D. Corporate Social Responsibility, Investor Behaviors, and Stock Market Returns: Evidence from a Natural Experiment in China. J. Bus. Ethics 2011, 101, 127-141. [CrossRef]

38. Bae, K.-H.; Kang, J.-K.; Kim, J.-M. Tunneling or Value Added? Evidence from Mergers by Korean Business Groups. J. Financ. 2002, 57, 2695-2740. [CrossRef]

39. Bertrand, M.; Mehta, P.; Mullainathan, S. Ferreting Out Tunneling: An Application to Indian Business Groups. Q. J. Econ. 2002, 117, 121-148. [CrossRef]

40. Young Chung, C.; Jung, S.; Young, J. Do CSR Activities Increase Firm Value? Evidence from the Korean Market. 2018. Available online: https://www.mdpi.com/2071-1050/10/9/3164 (accessed on 6 June 2019).

41. Choi, J.-S.; Kwak, Y.-M.; Choe, C. Corporate social responsibility and corporate financial performance: Evidence from Korea. Aust. J. Manag. 2010, 35, 291-311. [CrossRef]

42. Lang, M.; Lundholm, R. Cross-Sectional Determinants of Analyst Ratings of Corporate Disclosures. J. Account. Res. 1993, 31, 246-271. [CrossRef]

43. Leftwich, R.W.; Watts, R.L.; Zimmerman, J.L. Voluntary Corporate Disclosure: The Case of Interim Reporting. J. Account. Res. 1981, 19, 50-77. [CrossRef]

44. Dye, R.A. Disclosure of Nonproprietary Information. J. Account. Res. 1985, 23, 123-145. [CrossRef]

45. Hyun, E.; Yang, D.; Jung, H.; Hong, K. Women on Boards and Corporate Social Responsibility. Sustainability 2016, 8, 300. [CrossRef]

46. Black, B.S.; Kim, W.; Jang, H.; Park, K.S. How corporate governance affect firm value? Evidence on a self-dealing channel from a natural experiment in Korea. J. Bank. Financ. 2015, 51, 131-150. [CrossRef]

47. Jianu, I.; Jianu, I. The Share Price and Investment: Current Footprints for Future Oil and Gas Industry Performance. Energies 2018, 11, 448. [CrossRef]

48. Bitner, L.N.; Dolan, R.C. Assessing the relationship between income smoothing and the value of the firm. Q. J. Bus. Econ. 1996, 35, 16.

49. Durnev, A.R.T.; Kim, E.H.A.N. To Steal or Not to Steal: Firm Attributes, Legal Environment, and Valuation. J. Financ. 2005, 60, 1461-1493. [CrossRef]

50. Klapper, L.F.; Love, I. Corporate governance, investor protection, and performance in emerging markets. J. Corp. Financ. 2004, 10, 703-728. [CrossRef] 
51. Denis, D.J.; Denis, D.K.; Yost, K. Global Diversification, Industrial Diversification, and Firm Value. J. Financ. 2002, 57, 1951-1979. [CrossRef]

52. Ammann, M.; Oesch, D.; Schmid, M.M. Product Market Competition, Corporate Governance, and Firm Value: Evidence from the EU Area. Eur. Financ. Manag. 2013, 19, 452-469. [CrossRef]

53. Healy, P.; Serafeim, G.; Srinivasan, S.; Yu, G. Market Competition, Earnings Management, and Persistence in Accounting Profitability Around the World. 2014. Available online: https://link.springer.com/article/10.1007/ s11142-014-9277-8 (accessed on 6 June 2019).

54. Manchiraju, H.; Rajgopal, S. Does Corporate Social Responsibility (CSR) Create Shareholder Value? Evidence from the Indian Companies Act 2013. J. Account. Res. 2017, 55, 1257-1300. [CrossRef]

55. Heckman, J.J. Sample Selection Bias as a Specification Error. Econometrica 1979, 47, 153-161. [CrossRef]

56. Behn, B.K.; Choi, J.; Kang, T. Audit Quality and Properties of Analyst Earnings Forecasts. Account. Rev. 2008, 83, 327-349. [CrossRef]

57. Lawrence, A.; Minutti-Meza, M.; Zhang, P. Can Big 4 versus Non-Big 4 Differences in Audit-Quality Proxies Be Attributed to Client Characteristics? Account. Rev. 2011, 86, 259-286. [CrossRef]

(C) 2019 by the authors. Licensee MDPI, Basel, Switzerland. This article is an open access article distributed under the terms and conditions of the Creative Commons Attribution (CC BY) license (http://creativecommons.org/licenses/by/4.0/). 